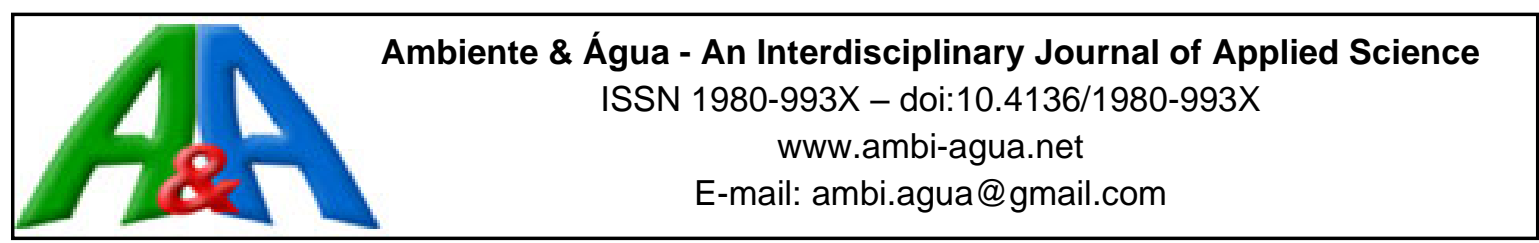

\title{
Impact of fulvic acid and free amino acids on paclobutrazol absorption by 'Keitt' mango
}

\author{
ARTICLES doi:10.4136/ambi-agua.2519
}

Received: 03 Feb. 2020; Accepted: 22 Jun. 2020

\section{Luan dos Santos Silva1 ${ }^{1}$; Paula Tereza de Souza e Silva ${ }^{2}$; Ítalo Herbert Lucena Cavalcante ${ }^{3 *(i D)}$}

\footnotetext{
${ }^{1}$ Departamento de Agronomia. Universidade Federal do Piauí (UFPI), Campus Prof ${ }^{a}$. Cinobelina Elvas, Rodovia BR 135, km 3, S/N, CEP: 64900-000, Bom Jesus, PI, Brazil. E-mail: luan_agronomia@ hotmail.com ${ }^{2}$ Embrapa Semiárido (EMBRAPA), Rodovia BR 428, Km 152, S/N, CEP: 56302-970, Petrolina, PE, Brazil. E-mail: paula.silva@embrapa.br

${ }^{3}$ Colegiado de Engenharia Agronômica. Universidade Federal do Vale do São Francisco (UNIVASF), Rodovia BR 407, 12 Lote 543, S/N, CEP: 56300-000, Petrolina, PE, Brazil.

*Corresponding author. E-mail: italo.cavalcante@univasf.edu.br
}

\begin{abstract}
This study evaluated the impact of fulvic acid and free amino acids on paclobutrazol soil residue, their absorption and effects on 'Keitt' mango grown in tropical semi-arid environmental conditions. The experiment was carried out from 2017 to 2018 simultaneously in two orchards with the same plants and management characteristics, located in Cabrobó, Pernambuco, Brazil. The experimental design was randomized blocks with four treatments, five replications and four plants per replication. The treatments consisted of paclobutrazol combinations with acid fulvic and free amino acids, as follows: Treatment 1: paclobutrazol + water (control); Treatment 2: paclobutrazol + fulvic acids; Treatment 3: paclobutrazol + free amino acids; and Treatment 4: paclobutrazol + fulvic acids + free amino acids. According to the results, the use of fulvic acids, free amino acids or both affects the paclobutrazol absorption by 'Keitt' mango. The addition of fulvic acid to the paclobutrazol improves the absorption of this molecule by the plant, with greater inhibition of vegetative growth of 'Keitt' mango and lower soil residues.
\end{abstract}

Keywords: Mangifera indica L., PBZ, soil contamination.

\section{Impacto de ácido fúlvico e aminoácidos livres na absorção do paclobutrazol pela mangueira 'Keitt'}

\section{RESUMO}

O objetivo deste estudo foi avaliar o impacto do ácido fúlvico e dos aminoácidos livres no resíduo de paclobutrazol no solo, absorção dessa molécula e seus efeitos sobre a mangueira 'Keitt' cultivada em condições do semiárido tropical. O experimento foi realizado de 2017 a 2018 simultaneamente em dois pomares com as mesmas plantas e características de manejo localizados em Cabrobó, Pernambuco, Brasil. O delineamento experimental foi em blocos ao acaso, com quatro tratamentos, cinco repetições e quatro plantas por repetição. Os tratamentos consistiram de combinações de paclobutrazol com ácido fúlvico e aminoácidos livres, sendo: Tratamento 1: paclobutrazol + água (controle); Tratamento 2: paclobutrazol + ácidos fúlvicos;

This is an Open Access article distributed under the terms of the Creative Commons Attribution License, which permits unrestricted use, distribution, and reproduction in any medium, provided the original work is properly cited. 
Tratamento 3: paclobutrazol + aminoácidos livres; e Tratamento 4: paclobutrazol + ácidos fúlvicos + aminoácidos livres. De acordo com os resultados, o uso de ácidos fúlvicos, aminoácidos livres ou ambos afetam a absorção de paclobutrazol pela manga 'Keitt'. A adição de ácido fúlvico ao paclobutrazol melhora a absorção desta molécula pela planta, com maior inibição do crescimento vegetativo da manga 'Keitt' e menores resíduos do solo.

Palavras-chave: contaminação do solo, Mangifera indica L., PBZ, substâncias húmicas.

\section{INTRODUCTION}

The São Francisco Valley, situated in the Brazilian semiarid, presents ideal climatic conditions for growing mangoes, but it must be associated with adequate management practices for soil fertility, irrigation, pruning and the use of plant-growth regulators (Mouco et al., 2010; Santos et al., 2019). One important mango cultivar for São Francisco Valley is 'Keitt', which is grown for exportation and, according to Genú and Pinto (2002), is a very productive plant, with typical growth represented by open and arched branches and leaves facing the base of the branches, promoting an irregular canopy shape. Thus, for this mango cultivar, the use of paclobutrazol (PBZ) has been usual.

PBZ is a plant growth regulator commonly used in mango production systems in semi-arid conditions (Carneiro et al., 2017; Oldoni et al., 2018; Cavalcante et al., 2018) to inhibit gibberellin biosynthesis and promote a better flowering uniformity (Srivastav et al., 2010).

The mechanism for PBZ absorption presents difficulties, due to its low solubility in water, low soil mobility and for reversibly binding to the plant vascular system and to the soil (Lever, 1986). However, PBZ can interact with soil organic matter, due to the presence of ionic (hydrophilic) groups that have high charge densities ( $\mathrm{OH}$ and triazole groups), and apolar (hydrophobic) groups related to the long carbon chains in their fractions (Milfont, 2008).

In the mango production system, PBZ is applied via soil dilution in water (soil drench) or directly applied in the canopy projection via the fertigation system, which is justified by the greater efficiency of the molecule applied in the soil instead of the foliar application (Mouco et al., 2011). However, the continuous use of PBZ year after year can contaminate soil and water resources (Silva et al., 2017), as well as negatively affect mango tree growth and development, excessively reducing branch growth and diameter (Cavalcante et al., 2020), and consequently the fruit production capacity of the plant, if the residue of previous applications are not considered (Vaz et al., 2015).

Thus, the use of organic molecules that can increase PBZ absorption and reduce the residue that remains in the soil with its continuous use can improve PBZ absorption efficiency, reduce its dose and, consequently, cause less risks to the environment and to the mango industry. Among these organic sources, amino acids and their analogues could be used, since they have agricultural applications as complexing substances for higher efficiency of ion and molecule absorption, due to better membrane permeability (Castro and Carvalho, 2014).

Another organic source with potential use are humic substances (SHs) that induce the $\mathrm{H}+$ -ATPase activity that provides energy to the secondary ion carriers and promote nutrient absorption (Canellas et al., 2015), activate ion metabolism and transport of different substances (Jannin et al., 2012). They also stimulate protein synthesis, photosynthesis, enzymatic activity, macro- and micronutrient solubilization, microbial activity and promote hormone-like effects (Seyedbagheri, 2010). Fulvic acids, particularly, have a lower molecular mass, due to their higher content of hydrophilic components and they are considered the most bioactive fraction of the humic substances (Nardi et al., 2007).

This study evaluated the impact of fulvic acid and free amino acids on paclobutrazol soil residue and their absorption and effects on 'Keitt' mango grown in tropical semi-arid environmental conditions.

Rev. Ambient. Água vol. 15 n. 4, e2519 - Taubaté 2020 


\section{MATERIAL AND METHODS}

\subsection{Characterization of the study area}

Two and one half years-old mango (Mangifera indica L.) plants, of the Keitt cultivar, with uniform size and vigor in the first production cycle were used in this study. The experiment was accomplished from 2017 to 2018 in an experimental orchard located in Cabrobó (08 $31^{\prime}$ 'S and $39^{\circ} 26^{\prime} \mathrm{W}$; at an altitude of $331 \mathrm{~m}$ above sea level), in Pernambuco, Brazil. The climate of this region is classified as Bswh (Köeppen), which corresponds to a semi-arid region. During the experiment, average air temperature and relative humidity ranged from $24.2^{\circ} \mathrm{C}$ to $29.4^{\circ} \mathrm{C}$ and from $57.8 \%$ and $79.2 \%$, respectively, with accumulated precipitation of $463 \mathrm{~mm}_{\text {year }}{ }^{-1}$.

The experiment was carried out simultaneously in two orchards with the same plant and management characteristics, in an experimental unit of $7.056 \mathrm{~m}^{2}$. The physical and chemical characteristics of the both soil orchards are described in Table 1.

Table 1. Chemical and physical characteristics of the soil in the 'Keitt' mango orchards studied.

\begin{tabular}{|c|c|c|c|c|c|c|c|c|c|c|c|}
\hline Orchard & Soil Layer & pH (in water) & $\mathbf{P}$ & $\mathbf{K}^{+}$ & $\mathrm{Na}^{+}$ & $\mathrm{Ca}^{2+}$ & $\mathrm{Mg}^{2+}$ & $\mathrm{Al}^{3+}$ & $\mathbf{H}+\mathbf{A l}$ & SB & $\mathbf{V}$ \\
\hline & M & & $\mathrm{mg} . \mathrm{dm}^{-3}$ & \multicolumn{6}{|c|}{$\mathrm{cmol}_{\mathrm{c}} \cdot \mathrm{dm}^{-3}$} & & $\%$ \\
\hline \multirow[b]{2}{*}{1} & $0.0-0.2$ & 4.94 & 66.62 & 0.41 & 1.22 & 2.52 & 1.43 & 0.35 & 4.29 & 5.58 & 56.55 \\
\hline & $0.2-0.4$ & 5.33 & 31.22 & 0.31 & 1.13 & 2.91 & 1.91 & 0.25 & 3.05 & 6.26 & 67.21 \\
\hline \multirow{2}{*}{2} & $0.0-0.2$ & 5.37 & 70.62 & 0.36 & 0.78 & 3.20 & 1.65 & 0.08 & 3.05 & 5.99 & 66.25 \\
\hline & $0.2-0.4$ & 6.22 & 44.28 & 0.64 & 1.70 & 3.06 & 1.92 & 0.08 & 1.98 & 7.31 & 78.70 \\
\hline \multirow[t]{2}{*}{ Orchard } & Soil layer & CEC (pH7) & $\mathbf{O M}$ & FA HA & $\mathbf{H U}$ & E.C. & Sand & Clay & Silt & \multicolumn{2}{|c|}{ Texture } \\
\hline & M & $\mathrm{cmol}_{\mathrm{c}} \cdot \mathrm{dm}^{-3}$ & & g. $\mathrm{kg}^{-1}$ & & $\mathrm{dS} \cdot \mathrm{m}^{-1}$ & & & dag. $\mathrm{kg}^{-1}$ & & \\
\hline \multirow[t]{2}{*}{1} & $0.0-0.2$ & 9.87 & 11.13 & 0.031 .44 & 4.45 & 0.06 & 51.13 & 15.90 & 32.97 & \multirow{2}{*}{\multicolumn{2}{|c|}{$\begin{array}{l}\text { Loam } \\
\text { Loam }\end{array}$}} \\
\hline & $0.2-0.4$ & 9.31 & 10.68 & 1.011 .30 & 4.02 & 0.07 & 48.32 & 18.10 & 33.58 & & \\
\hline & $0.0-0.2$ & 9.04 & 13.13 & 0.071 .61 & 4.95 & 0.15 & 48.94 & 14.10 & 36.96 & \multirow{2}{*}{\multicolumn{2}{|c|}{$\begin{array}{c}\text { Loam } \\
\text { Sand Loam }\end{array}$}} \\
\hline & $0.2-0.4$ & 9.29 & 9.68 & 0.841 .62 & 5.53 & 0.17 & 54.81 & 16.40 & 28.79 & & \\
\hline
\end{tabular}

$\mathrm{SB}=$ sum of bases $\left(\mathrm{Ca}^{2+}+\mathrm{Mg}^{2+}+\mathrm{Na}^{+}+\mathrm{K}^{+}\right) ; \mathrm{OM}=$ Organic matter; $\mathrm{CEC}=$ cationic exchangeable capacity $\left[\mathrm{Ca}^{2+}+\mathrm{Mg}^{2+}+\mathrm{Na}^{+}+\mathrm{K}^{+}+\left(\mathrm{H}^{+}+\mathrm{Al}^{3+}\right)\right]$; E.C. = electrical conductivity; P, K: Melich-1; $\mathrm{H}+$ $\mathrm{Al}$ : calcium acetate (extractor) $0.5 \mathrm{M}, \mathrm{pH} 7 ; \mathrm{Al}, \mathrm{Ca}, \mathrm{Mg}$ : $\mathrm{KCl} 1 \mathrm{M}$ extractor.

For chemical characterization, the values of electrical conductivity in the saturation paste extract (E.C.), $\mathrm{pH}\left(\mathrm{H}_{2} \mathrm{O}\right)$, potential acidity $(\mathrm{H}+\mathrm{Al})$, exchangeable acidity $\left(\mathrm{Al}^{3+}\right)$ and total organic matter $(\mathrm{OM})$, potassium $\left(\mathrm{K}^{+}\right)$, calcium $\left(\mathrm{Ca}^{2+}\right)$, magnesium $\left(\mathrm{Mg}^{2+}\right)$ and phosphorus $(\mathrm{P})$ were determined, according to the methodology proposed by Silva (2009). The fractionation of humic substances was carried out according to the method suggested by the International Humic Substances Society (Swift, 1996). From this fractionation, the fractions of fulvic acids (FA), humic acids (HA) and humines (HU) were obtained, based on the solubility in acidic or alkaline solutions. Physical analyses were done by granulometry, determined by the pipette method (Donagema et al., 2011).

The plants, spaced with $4.0 \mathrm{~m}$ between the rows and $2.0 \mathrm{~m}$ between the plants, were dripirrigated daily, with four emitters per plant, for a flow of nearly $2 \mathrm{~L} \mathrm{~h}^{-1}$ for each emitter. All management practices such as pruning, control of weeds, pests and diseases, plant growth regulators for gibberellin inhibition (paclobutrazol, Cultar ${ }^{\circledR}$ ) and dormancy break (calcium nitrate and potassium nitrate) were performed following the instructions of Genú and Pinto (2002). Nutrient management was performed through a fertirrigation system, according to plant demand (Genú and Pinto, 2002). An additional pruning was performed at 27 days after paclobutrazol treatment to keep each plant with nearly 100 shoots, and tip pruning was 
performed to synchronize vegetative flush events in the canopy.

\subsection{Experimental design and application of treatments}

The experiment followed a "randomized blocks" design with four treatments, five replications per treatment and four plants per replication. The treatments consisted of paclobutrazol (PBZ) combinations with acid fulvic and free amino acids, as follows: T1: PBZ + water (control); T2: PBZ + fulvic acids; T3: PBZ + free amino acids; and T4: PBZ + fulvic acids + free amino acids. The control treatment consisted of PBZ application, because under tropical semi-arid conditions the mango production system becomes economically viable by using this molecule (Genú and Pinto, 2002).

The PBZ source used was Cultar SC ${ }^{\circledR}$ (25\% i.a. paclobutrazol). Treatments were applied through the fertigation system once at 30 days after production pruning, when plants presented a $2.0 \mathrm{~m}$ canopy diameter. The sources of the acid fulvic and free amino acids used were, respectively: $16 \mathrm{ml}$ per plant of Aminoagro $\mathrm{Mol}^{\circledR}\left(10 \%\right.$ of $\mathrm{N}, 1 \%$ of $\mathrm{K}_{2} \mathrm{O}$ and $8 \%$ of total organic carbon) and $16 \mathrm{ml}$ per plant of Aminoplus ${ }^{\circledR}\left(11 \%\right.$ of $\mathrm{N}, 1 \%$ of $\mathrm{K}_{2} \mathrm{O}, 6 \%$ of total organic carbon, and glutamate). The treatments were applied following the recommendations of Genú and Pinto (2002) for mango tree and the product manufacturers.

\subsection{Analyzed variables}

PBZ analyses were performed in roots and in the last vegetative flush. Before the application of PBZ + organic acids (December 20, 2017), an orchard-soil characterization (OC) was carried out, and on later dates seven other evaluations were done, with plant material collected between 10:00 am and 11:00 am to standardize the time and minimize any potential climate effect.

The roots up to $4 \mathrm{~mm}$ in diameter were collected up to $0.3 \mathrm{~m}$ deep and $0.25 \mathrm{~m}$ from the mango trunk, in the projection of the irrigation system, which consisted of two drip lines (one on each side of the plant) parallel to the plant rows, with $0.5 \mathrm{~m}$ spacing between the drippers, totaling four plants. The last fully expanded vegetative flush was collected from the middle third of the four quadrants of the canopy, avoiding necrotic areas due to pest and disease attack.

The plant material was conducted to the laboratory, where it was washed, air dried (shade conditions) and milled in a Willey-type Knife Mill with $0.5 \mathrm{~mm}$ sieves. The soil PBZ residue was evaluated 272 days after PBZ application (at harvest). A soil sample was collected for each replicate of the treatments, from 0 to $0.4 \mathrm{~m}$ depth, transported to the laboratory, air dried (shade conditions) and then sifted with a $2.0 \mathrm{~mm}$-mesh sieve.

The residual PBZ analysis was based on the extraction methodology of QuEChERS and determination by high performance liquid chromatography (HPLC) confirmed by Silva et al. (2017), with adaptations.

An estimation of PBZ in all plant vegetative flushes was also performed through the concentration found in the last vegetative flush of each treatment and at each evaluation date, multiplying by the total number of shoots per plant.

The shoot length $(\mathrm{cm})$ and diameter $(\mathrm{mm})$ were measured every 15 days, from the orchard characterization (OC) (December 13, 2017) until 75 days after the beginning of the experiment (floral induction), reaching six dates. Ten shoots were marked per plant, distributed by the four quadrants in the median portion of the canopy.

\subsection{Statistical analysis}

The data obtained of shoot length and diameter was subjected to the analysis of variance (ANOVA). All statistical analyses were performed using the SISVAR and SIGMAPLOT, and averages were compared by the Tukey test at $p<0.05$.

Rev. Ambient. Água vol. 15 n. 4, e2519 - Taubaté 2020 


\section{RESULTS AND DISCUSSION}

\subsection{Paclobutrazol residue in the mango tree}

In Figure 1 are shown the average results of the PBZ residue in roots and in the last vegetative flush of the 'Keitt' mango in different phenological phases in the two orchards studied (Orchard 1 and Orchard 2).
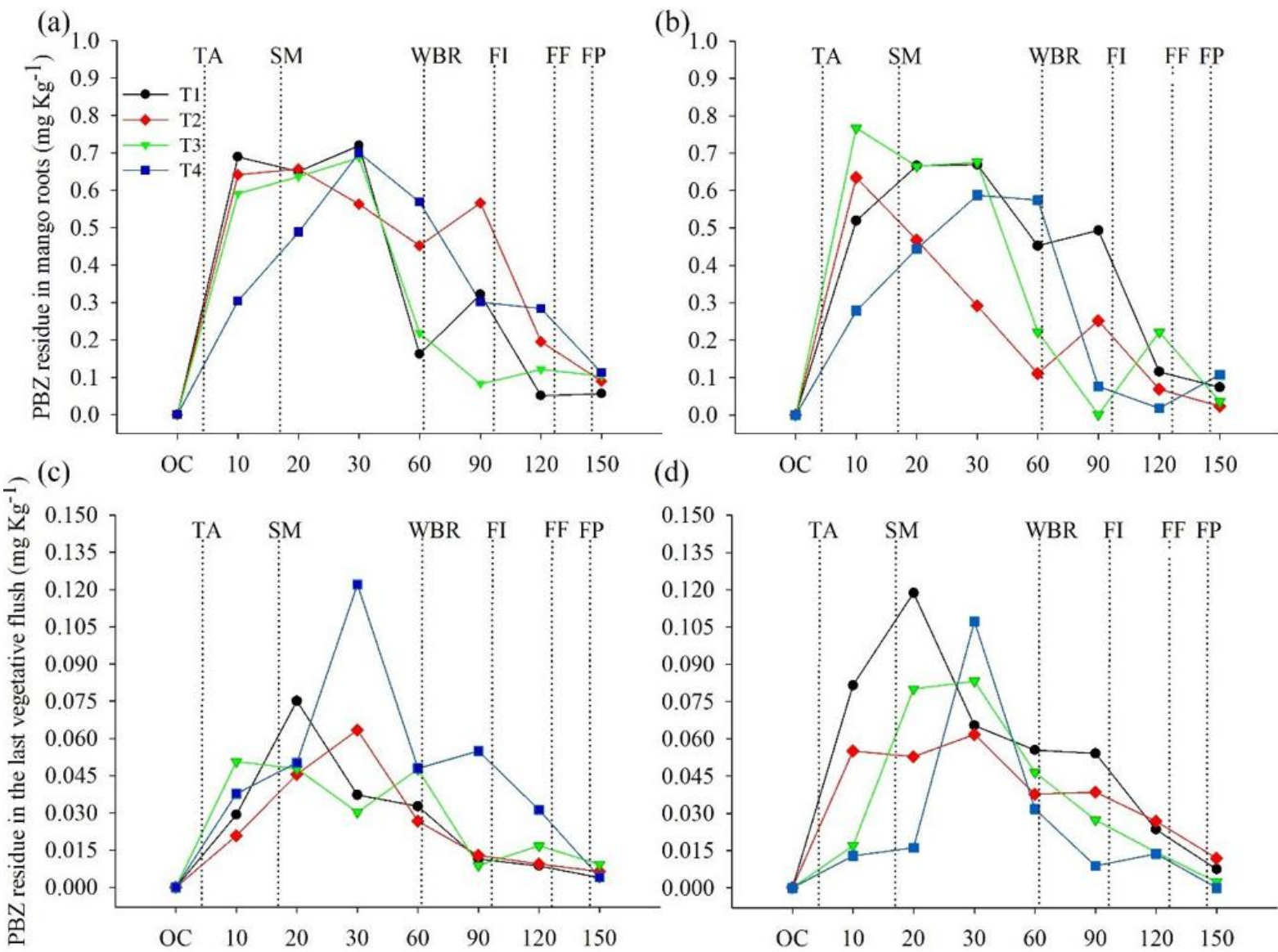

Figure 1. PBZ residue in mango roots [orchard 1 (a); orchard 2 (b)] and in the last vegetative flush [orchard 1 (c); orchard 2 (d)] of mango 'Keitt' as a function of fulvic acids and free amino acids.T1: PBZ + water (control); T2: PBZ + fulvic acids; T3: PBZ + free amino acids; and T4: PBZ + fulvic acids + free amino acids. OC: orchard characterization (12/09/2017); TA: treatment application; SM: shoot maturation; WBR: water blade reduction; FI: flowering induction; FF: full flowering; FP: fruit size 'pellet'.

The PBZ uptake was quite rapid for treatments T1, T2 and T3, because at 10 days after PBZ application (DAP) all were above $0.50 \mathrm{mg} \mathrm{kg}^{-1}$, whereas T4 contained less than $0,31 \mathrm{mg}$ $\mathrm{kg}^{-1}$ in Orchards 1 and 2, respectively (Fig. $1 \mathrm{a}-\mathrm{b}$ ). At 30 DAP the PBZ levels of T1, T3 and T4 remained high and $\mathrm{T} 2$ declined.

PBZ in T2 was more rapidly translocated to the plant aerial part, while the other treatments (T1 and T3) continued practically with the same root PBZ amount, and the T4 continued to be absorbed slowly because fulvic acids (FA) promoted a greater mobility to PBZ molecules in the soil, mainly due to their large specific surface area, high density of loads and smaller size (Canellas et al., 2015).

The negative charges of the humic substances react with the organic compounds containing $\mathrm{N}$, in this case with the triazole (PBZ), forming a complex (Sposito, 2008), resulting in less load resistance in comparison to the non-complexed molecule.

It is also necessary to emphasize that the PBZ residue amount in roots is much higher than 
the concentrations in the last vegetative flush, and even with time elapsing this difference persists.

Despite the low mobility of this molecule, the highest PBZ absorption level occurred shortly after its application, since it was directed to the most active root zones through fertigation. However, from BWR to FI, root PBZ increased for T1 and T2 in both orchards (Figure $1 \mathrm{a}-\mathrm{b}$ ), which may have been caused by the water potential reduction caused by the accumulation of solutes near the root zones (Taiz et al., 2017). However, T3 and T4, both with amino acids, did not maintain PBZ available for the plant until 90 DAP, proving to be less effective with time elapsing.

PBZ receives oxygen from the cytochrome $\mathrm{P} 450$, avoiding the ent-caurene oxygenation (Srivastav et al., 2010). There must be a ratio between the amount of ent-caurenoic acid that is not formed and the number of PBZ molecules that are effectively used in inhibiting gibberellin formation.

After the water blade reduction (WBR), the levels of PBZ in the last vegetative flush began to decline for all treatments until the 'pellet' fruit size (FP) phase, with values below $0.02 \mathrm{mg}$ $\mathrm{kg}^{-1}$. Higher values were reported by Bhattacherjee and Singh (2015) in mango leaves cv. Dashehari ( 0.8 and 1.6 g i.a. plant $\left.^{-1}\right)$, which promoted 0.32 and $0.56 \mathrm{mg} \mathrm{kg}^{-1}$ at 120 DAP. These authors performed fourteen readings from 0 to 360 DAP and on seven reading dates (almost totally intercalated), PBZ was not detected in leaves, and the authors attributed this result to the molecule biodegradation in leaves or to the reduction of PBZ hydraulic conductivity by leaves.

Figure 2 contains the PBZ estimation in all last vegetative flushes of the plants. A very similar tendency to that recorded for the last vegetative flush (Figure $1 \mathrm{c}$-d) can be observed, because the plants were quite uniform, having approximately 100 productive shoots per plant.

(a)

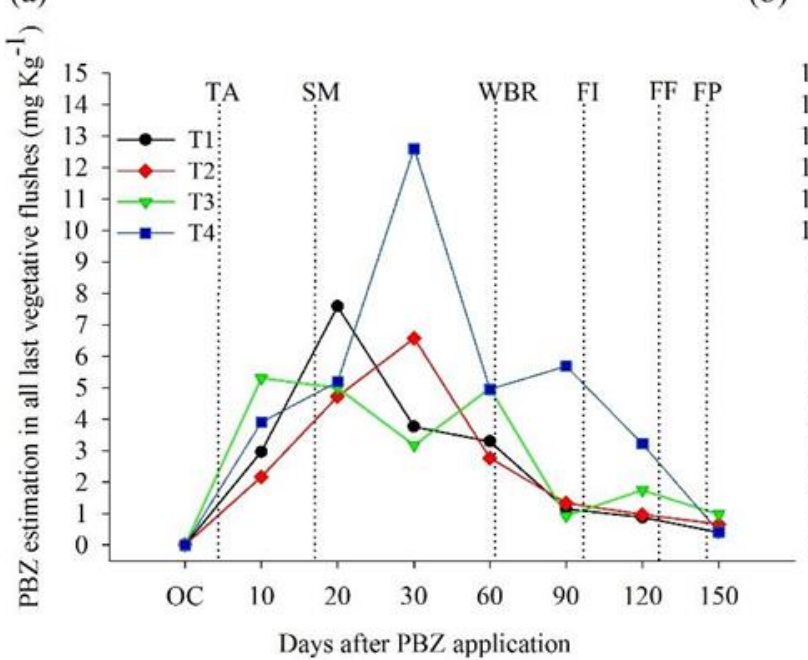

(b)

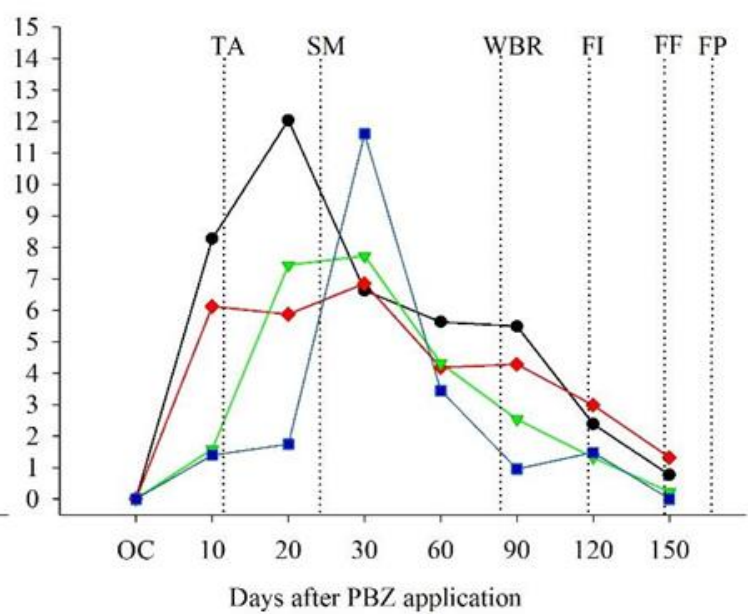

Figure 2. PBZ estimation in all last vegetative flushes [orchard 1 (a); orchard 2 (b)] of 'Keitt' mango as a function of fulvic acids and free amino acids.

T1: PBZ + water (control); T2: PBZ + fulvic acids; T3: PBZ + free amino acids; and T4: PBZ + fulvic acids + free amino acids. OC: orchard characterization (12/09/2017); TA: treatment application; SM: shoot maturation; WBR: water-blade reduction; FI: flowering induction; FF: full flowering; FP: fruit size - 'pellet'.

In spite of the notorious effects of FA on T2, treatment T4, which also has FA, presented less efficient results, such as slow root absorption (Figure $1 \mathrm{a}-\mathrm{b}$ ) and the late peak of PBZ at 30 DAP (Figure $2 \mathrm{a}-\mathrm{b}$ ), probably because the FA can react with the amino acids (containing two protonatable $\mathrm{NH}_{2}$ groups) by cation exchange and form some complex between them (Baldotto 
and Baldotto, 2014), resulting in a smaller amount of complexes with PBZ, delaying its soil transport, and consequently its absorption, due to the competition for absorption of other molecules.

The best PBZ absorption was promoted by the use of fulvic acid (FA) individually (T2) that can be explained by the hydrophobic and hydrophilic interactions between PBZ and organic matter (OM), which increases PBZ adsorption (Milfont et al., 2008). Thus, a greater amount of PBZ remains available to the plant for longer, because it is translocated along with the OM, mainly by FA, since these have lower molecular mass and thus greater ease of movement in the soil, near the root zones and inside the plant (Nardi et al., 2007).

\subsection{Paclobutrazol residue in soil}

At the end of the experiment, there was a remarkable difference for soil PBZ residue, emphasizing that T2 promoted the lowest soil PBZ residue amount (Figure 3). This result indicates that $\mathrm{T} 2$ promoted an efficient PBZ use and it reduces environmental impacts.

(a)

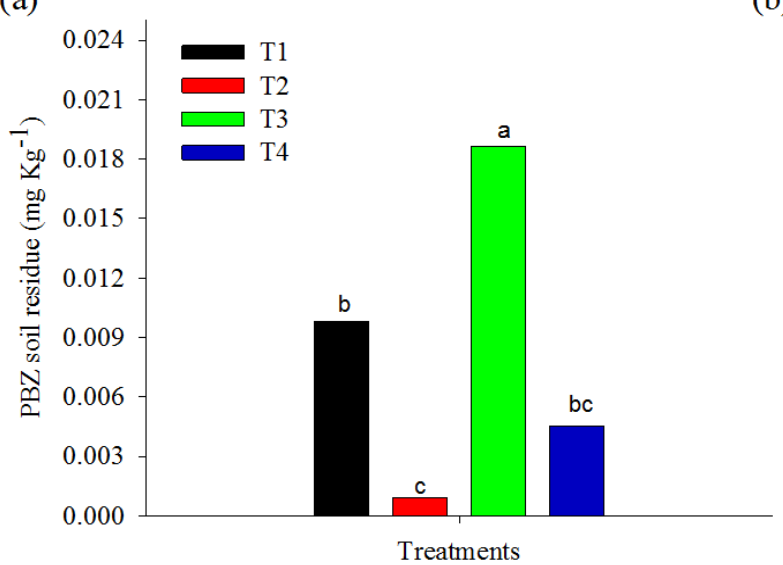

(b)

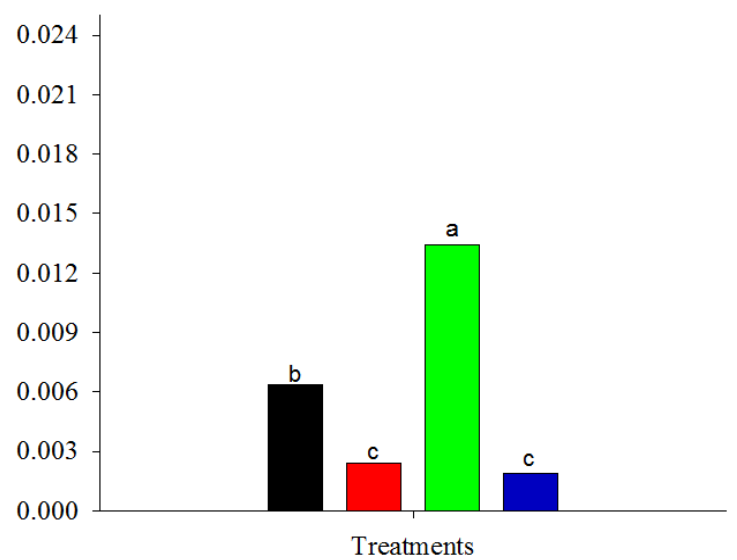

Figure 3. PBZ soil residue [orchard 1 (a); orchard 2 (b)] in orchards of 'Keitt' mango as a function of fulvic acids and free amino acids, at 272 after treatments.

T1: PBZ + water (control); T2: PBZ + fulvic acids; T3: PBZ + free amino acids; and T4: PBZ + fulvic acids + free amino acids. Bars with the same letters do not differ among themselves by Tukey's test at $5 \%$ probability error.

With the initial increase and final reduction of PBZ levels in the plant, it is possible to observe that the PBZ was gradually used during mango phenological phases, then the fastest decrease in $\mathrm{T} 2$ shows that it was used more rapidly during the shoot maturation phase in both orchards (Figure 2), which is quite interesting for the crop, due to the need to accumulate carbohydrates as a function of PBZ use (Prasad et al., 2014).

Another possibility is the effect of humic substances on the stimulation of auxin synthesis, responsible for cell expansion and stretching (Trevisan et al., 2010). The expansion is related to the synthesis of $\mathrm{H}^{+}$-ATPase pumping protons to form ATP, causing a variation in the electrochemical potential, reducing the apoplast $\mathrm{pH}$, making the cell wall more flexible, thereby facilitating root growth (Zandonadi et al., 2010 ), mainly lateral roots, which are more important for water and nutrient absorption (Caron et al., 2015). This may explain the lower soil PBZ residue promoted by the treatments with $F A$.

The PBZ remains active in the soil for a long period, but it is affected by the soil type and climatic conditions (Costa et al., 2012).

The soil PBZ residues of the present study were below those found by Bhattacherjee and Singh (2015), where 300 days after the application of 0.8 and $1.6 \mathrm{~g}$ a.i. PBZ plant ${ }^{-1}$ detected $^{-1}$ 0.01 and $0.03 \mathrm{mg} \mathrm{kg}^{-1}$, respectively, and residue in leaves was detected after 60 days $(30 \mathrm{~d}$ interval measurements), showing that it was translocated more slowly to the shoots than have 
shown the results of the present study.

It is emphasized that Bhattacherjee and Singh (2015) applied the PBZ in a soil drench in a radial diameter of $1 \mathrm{~m}$ from the tree trunk (conventional application), which is significantly less effective than the fertigation used in the present study (Souza et al., 2018). Silva et al. (2017) evaluated soil PBZ concentrations using the same method of the present study ('QuEChERS' and determination by HPLC) and found average values varying from 0.14 to $6.86 \mathrm{mg} \mathrm{kg}^{-1}$ in soils with different mango cultivars, finding that 'Keitt' orchards presented concentrations from 1.49 to $0.18 \mathrm{mg} \mathrm{kg}^{-1}$ at $150 \mathrm{DAP}$, which are higher values than the present study (Figure 3).

\subsection{Shoot vegetative growth of the mango tree}

In relation to the shoot vegetative growth, the PBZ action was very fast, since it presented a significant effect at 15 DAP in both orchards, reducing the shoot length of all treatments (Figure $4 \mathrm{a}-\mathrm{b}$ ). However, there were significant differences between T2 and T3 in Orchard 1 from day 30 onwards, with T2 having the lowest values (Figure $4 \mathrm{a}-\mathrm{b}$ ).

(a)

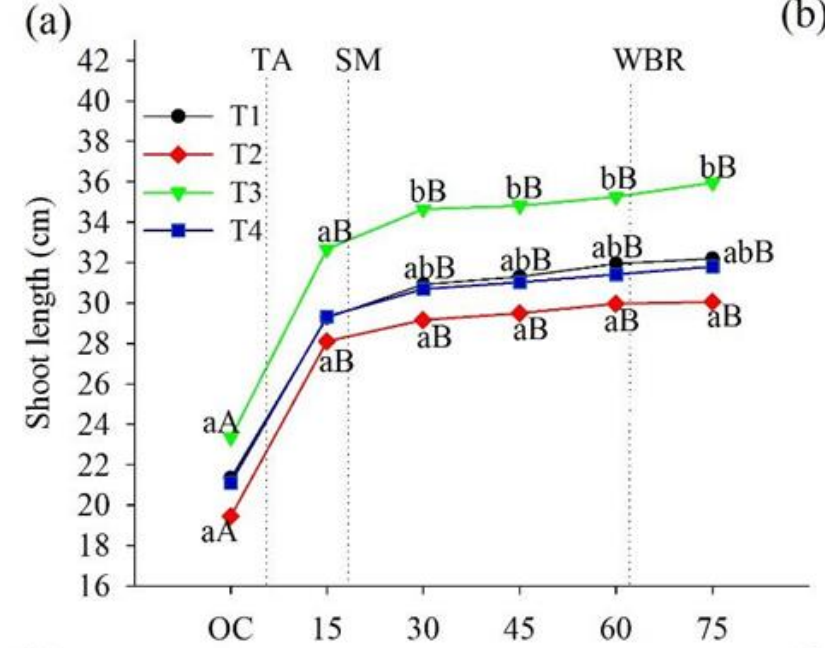

(c)

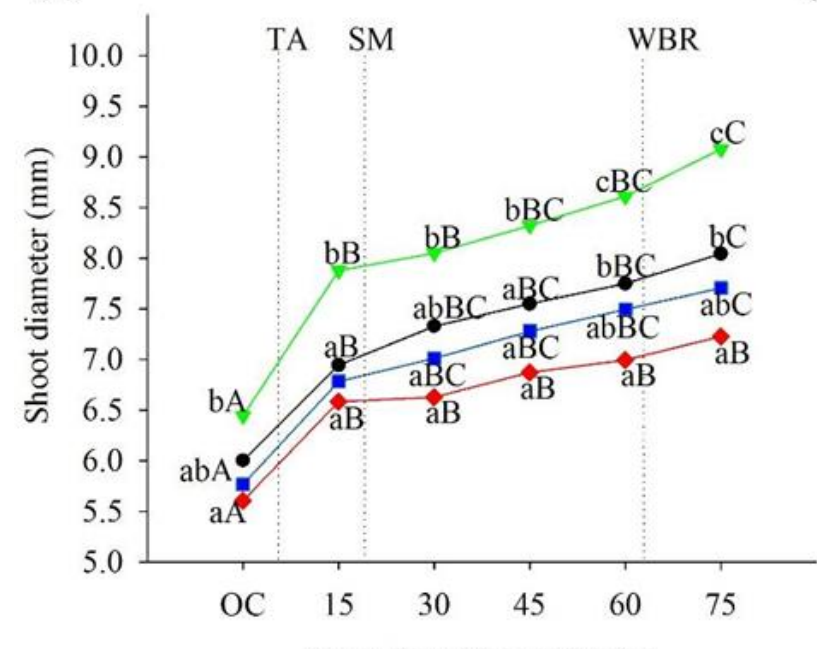

Days after PBZ application (b)

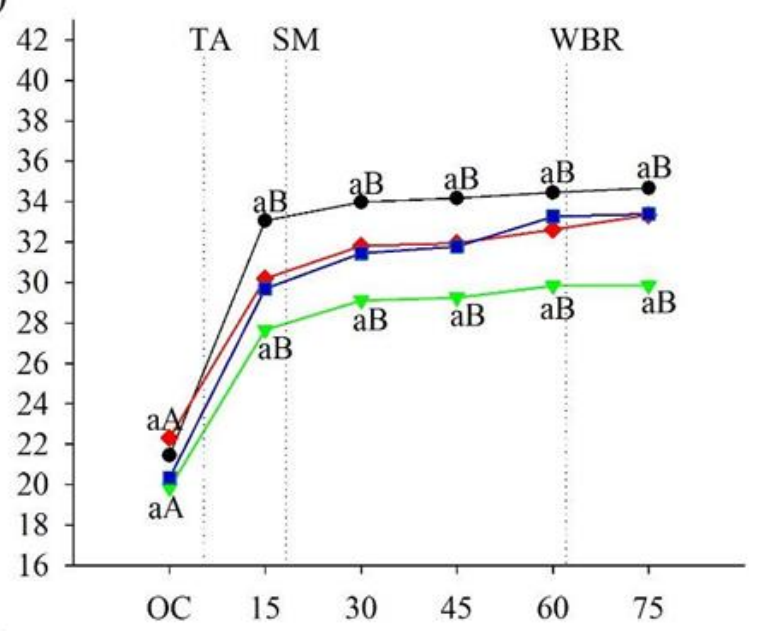

(d)

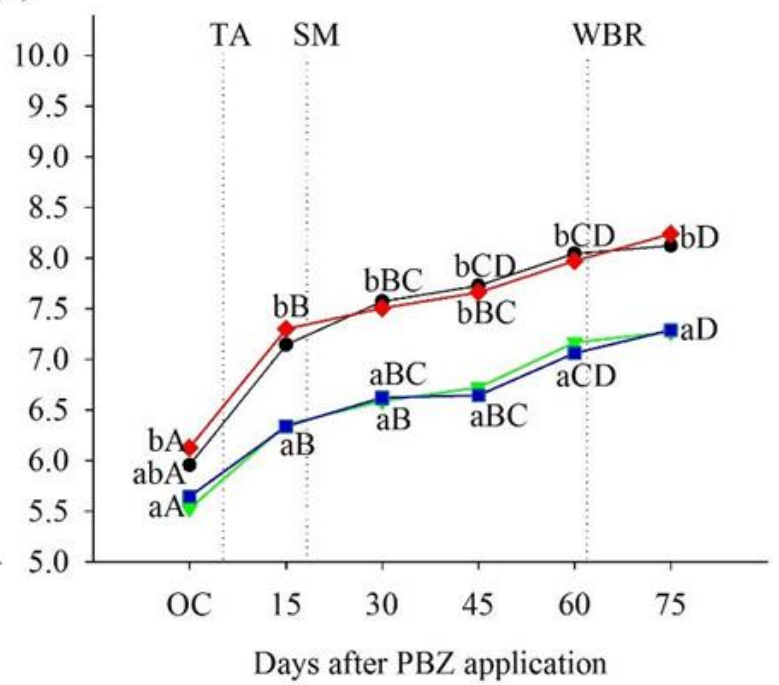

Figure 4. Shoot length [orchard 1 (a); orchard 2 (b)] and shoot diameter [orchard 1 (c); orchard 2 (d)] of 'Keitt' mango as a function of fulvic acids and free amino acids. T1: PBZ + water (control); T2: PBZ + fulvic acids; T3: PBZ + free amino acids; and T4: PBZ + fulvic acids + free amino acids. OC: orchard characterization (12/09/2017); TA: treatment application; SM: shoot maturation; WBR: water blade reduction. 
Mouco et al. (2011) registered shoots $4.98 \mathrm{~cm}$ shorter as a function of PBZ use (4.0 g a. i. plant $^{-1}$ ) when compared to the control in 'Kent' mango cultivar. Meena et al. (2014) states that the shorter shoot length recorded in PBZ treated plants occurs due to gibberellin suppression, since they act in the cell elongation, and in these conditions, although cell division continues to occur, the new cells are not elongated, resulting in shortened internodal lengths.

For the diameter of the last vegetative flush, in Orchard 1, only T3 was different from the control, although this has already been observed even before PBZ application (AC) (Figure 4 c-d). In Orchard 2, T3 and T4 were lower than T1, and similar to each other. In relation to dates, shoot growth was slow but progressive for all treatments in both orchards.

It has been reported that the PBZ does not act or has little influence on the secondary growth responsible for the increase of plant diameter, due to the activity of the vascular exchange and the felogen (Meena et al., 2014; Hegde et al., 2018). However, this is a pioneer assessment, and perhaps the concentration of the sources used was not enough to express greater efficiency on this variable.

\section{CONCLUSION}

The use of fulvic acids, free amino acids or both affects PBZ absorption by the 'Keitt' mango.

The addition of fulvic acid to the PBZ improves the absorption of this molecule by the plant, with greater inhibition of vegetative growth of the 'Keitt' mango.

At the end of the productive cycle, there is a lower soil PBZ residue when it is applied together with fulvic acid, and therefore this treatment can be recommended for mango crop management in semi-arid conditions.

\section{REFERENCES}

BAldotTo, M. A.; BALdotTO, L. E. B. Ácidos húmicos. Revista Ceres, v. 61, p. 856881, 2014. https://doi.org/10.1590/0034-737x201461000011

BHATTACHERJEE, A. K.; SINGH, V. K. Uptake of soil applied paclobutrazol in mango cv. Dashehari and its persistence in soil, leaves and fruits. Indian Journal of Plant Physiology, v. 20, n.1, p. 39-43, 2015. https://doi.org/10.1007/s40502-014-0135-2

CANELlAS, L. P.; OLIVARESA, F. L.; AGUIAR, N. O.; JONES, D. L.; NEBBIOSOC, A.; MAZZEIC, P.; PICCOLO, A. Humic and fulvic acids as biostimulants in horticulture. $\begin{array}{llllll}\text { Scientia Horticulturae, } & \text { v. } & 196, & \text { p. }\end{array}$ https://doi.org/10.1016/j.scienta.2015.09.013

CARNEIRO, M. A.; LIMA, A. M. N., CAVALCANTE, I. H. L., CUNHA, J. C., RODRIGUES, M. S.; LESSA, T. B. S. Soil salinity and yield of mango fertigated with potassium sources. Revista Brasileira de Engenharia Agrícola e Ambiental, v. 21, n. 5, p. 310-316, 2017. https://doi.org/10.1590/1807-1929/agriambi.v21n5p310-316

CARON, V. C.; GRAÇAS, J. P.; CASTRO, P. R. C. Condicionadores do solo: ácidos húmicos e fúlvicos. Piracicaba: ESALQ/USP, 2015. 46 p.

CASTRO, P. R. C. E; CARVALHO, M. E. A. Aminoácidos e suas aplicações na agricultura. Piracicaba: ESALQ/USP, 2014. 58 p.

CAVALCANTE, Í. H. L.; NOGUEIRA e SILVA, G. J.; CAVACINI, J. A.; AMARIZ, R. A.; FREITAS, S. T.; SOUSA, K. A. O.; SILVA, M. A.; CUNHA, J. G. Metconazole on inhibition of gibberellin biosynthesis and flowering management in mango. ErwerbsObstbau, v. 62, p. 89-95, 2020. https://doi.org/10.1007/s10341-019-00466-w 
CAVALCANTE, Í. H. L.; SANTOS, G. N. F.; SILVA, M. A.; MARTINS, R. S.; LIMA, A. M. N.; MODESTO, P. I. R.; AlCOBIA, A. M.; SILVA, T. R. S.; AMARIZ, R. A.; BECKMANN-CAVALCANTE, M. Z. A new approach to induce mango shoot maturation in Brazilian semi-arid environment. Journal of Applied Botany and Food Quality, v. 91, p. 281-286, 2018.

COSTA, M. A.; TORRES, N. H.; VILCA, F. Z.; NAZATO, C.; TORNISIELO, V. L. Residue of 14 C-Paclobutrazol in mango. International Organization of Scientific Research Journal of Engineering, v. 2, n. 1, p. 1165-1167, 2012.

DONAGEMA, G. K.; CAMPOS, D. B.; CALDERANO, S. B.; TEIXEIRA, W. G.; VIANA, J. M. Manual de métodos de análise de solo. 2. ed. Rio de Janeiro: Embrapa Solos, 2011, 230p.

GENÚ, P. J. C.; PINTO, C. A. Q. A cultura da mangueira. Brasília: Embrapa Informação Tecnológica, 2002. $452 \mathrm{p}$.

HEGDE, S.; ADIGA, J. D.; HONNABYRAIAH, M. K.; GURUPRASAD, T. R.; SHIVANNA, M.; HALESH, G. K. Influence of Paclobutrazol on growth and yield of Jamun cv. Chintamani. International Journal of Current Microbiology and Applied Sciences, v. 7, n. 1, p. 1590-1599, 2018.

JANNIN, L.; ARKOUN, M.; OURRY, A.; LAÎNÉ, P.; GOUX, D.; GARNICA, M.; FUENTES, M.; FRANCISCO, S. S.; BAIGORRI, R.; CRUZ, F.; HOUDUSSE, F.; GARCIA-MINA, J.-M.; YVIN, J.-C.; ETIENNE, P. Microarray analysis of humic acid effects on Brassica napus growth: involvement of N, C and S metabolisms. Plant and soil, v. 359, n. 1-2, p. 297-319, 2012. https://doi.org/10.1007/s11104-012-1191-x

LEVER, B. G. 'Cultar' - A technical overview. Acta Horticulturae, v. 179, p. 459-466, 1986. https://doi.org/10.17660/ActaHortic.1986.179.71

MEENA, R. K.; ADIGA, J. D.; NAYAK, M. G.; SAROJ, P. L.; KALAIVANAN, D. Effect of Paclobutrazol on growth and yield of Cashew (Anacardium occidentale L.). Indian Society Plant Research, v. 27, n.1, p. 11-16, 2014. https://dx.doi.org/10.5958/j.22294473.27.1.003

MILFONT, M. L.; ANTONINO, A. C. D.; MARTINS, J. M. F.; NETTO, A. M.; GOUVEIA, E. R.; CORREA, M. M. Transporte do paclobutrazol em colunas de solos. Revista Brasileira de Ciência do Solo, v. 32, n. 5, p. 2165-2175, 2008. http://dx.doi.org/10.1590/S0100-06832008000500037

MOUCO, M. A. C.; ONO, E. O.; RODRIGUES, J. D. Inibidores de síntese de giberelinas e crescimento de mudas de mangueira 'Tommy Atkins'. Ciência Rural, v. 40, n.2, p. 273 279, 2010. https://doi.org/10.1590/S0103-84782010000200004

MOUCO, M. D. C.; ONO, E. O.; RODRIGUES, J. D. Controle do crescimento vegetativo e floração de mangueiras cv. Kent com reguladores de crescimento vegetal. Revista Brasileira de Fruticultura, v. 33, n.4, p. 1043-1047, 2011. https://doi.org/10.1590/S0100-29452011000400001

NARDI, S.; MUSCOLO, A.; VACCARO, S.; BAIANO, S.; SPACCINI, R.; PICCOLO, A. Relationship between molecular characteristics of soil humic fractions and glycolytic pathway and krebs cycle in maize seedlings. Soil Biology and Biochemistry, v. 39, n. 12, p. 3138-3146, 2007. https://doi.org/10.1016/j.soilbio.2007.07.006 
OLDONI, F. C. A.; LIMA, A. M. N.; CAVALCANTE, Í. H. L.; SOUSA, K. S. M.; CARNEIRO, M. A.; CARVALHO, I. R. B. Boron fertilizing management on fruit production and quality of mango cv. Palmer in semiarid. Revista Brasileira de Fruticultura, v. 40, n. 3, p. 1-8, 2018. http://dx.doi.org/10.1590/0100-29452018622

PRASAD, S. S.; REDDY, Y. T. N.; UPRETI, K. K.; RAJESHWARA, A. N. Studies on changes in carbohydrate metabolism in regular bearing and "Off" season bearing cultivars of mango (Mangifera indica L.) during flowering. International Journal of Fruit Science, v. 14, n. 4, p. 437-459, 2014. https://doi.org/10.1080/15538362.2014.897891

SANTOS, L. R. dos; LIMA, A. M. N.; RODRIGUES, M. S.; CUNHA, J. C.; SANTOS, L. P. A. dos; SOARES, E. M. B.; SILVA, A. V. L. da; SOUZA, I. M. de. Does the irrigated mango cultivation in the semiarid change the physical and chemical attributes of the soil?. $\begin{array}{llllllll}\text { Comunicata Scientiae, } & \text { v. } 10, \quad \text { n. } & 3, & \text { p. } & 402-414,\end{array}$ https://doi.org/10.14295/cs.v10i3.2966

SEYEDBAGHERI, M. M. Influence of humic products on soil health and potato production. Potato Research, v. 53, n. 4, p. 341-349, 2010. https://doi.org/10.1007/s11540-0109177-7

SILVA, F. C. (ed.) Manual de análises químicas de solos, plantas e fertilizantes. Brasília: Embrapa Informação Tecnológica, 2009. 627p.

SILVA, P. T. S.; SOUZA, L. S. S.; NETA, C. R.; MOUCO, M. A.; SIMOES, W.; FERRAZ, A. Análise de paclobutrazol em solos de áreas cultivadas com diferentes variedades de mangueira no Vale do São Francisco empregando QuEcHers e CLAE. Scientia Plena, v. 13, n. 9, p. 1-9, 2017. http://dx.doi.org/10.14808/sci.plena.2017.097201

SOUZA, M. A. de; SIMÕES, W. L.; MESQUISTA, A. C.; MOUCO, M. A. C.; CAVANCANTE, B. L. S.; GUIMARÃES, M. J. M. Manejo da quimigação para indução floral da mangueira "Palmer" no Submédio do Vale do São Francisco. Irriga, v. 23, n. 3, p. 442-453, 2018. https://doi.org/10.15809/irriga.2018v23n3p442-453

SPOSITO, G. The chemistry of soils. 2. ed. New York: Oxford university press, 2008. 344 p.

SRIVASTAV, M.; KISHOR, A.; DAHUJA, A.; SHARMA, R. R. Effect of paclobutrazol and salinity on ion leakage, proline content and activities of antioxidant enzymes in mango (Mangifera indica L.). Scientia Horticulturae, v. 125, n. 4, p. 785-788, 2010. https://doi.org/10.1016/j.scienta.2010.05.023

SWIFT, R. S. Organic matter characterization. In: SPARKS, D. L.; PAGE, A. L.; HELMKE, P. A.; LOEPPERT. R. H. (eds.). Methods of Soil Analysis. Part 3. Chemical Methods. Madison: Soil Science Society of America, 1996. p. 1011-1069.

TAIZ, L.; ZEIGER, E.; MØLLER, I. M.; MURPHY, A. Fisiologia e desenvolvimento vegetal. 6. ed. Porto Alegre: Artmed, 2017. 888 p.

TREVISAN, S.; PIZZEGHELLO, D.; RUPERTI, B.; FRANCIOSO, O.; SASSI, A.; PALME, K.; QUAGGIOTTI, S.; NARDI, S. Humic substances induce lateral root formation and expression of the early auxin-responsive IAA19 gene and DR5 synthetic element in Arabidopsis. Plant Biology, v. 12, n. 4, p. 604-614, 2010. https://doi.org/10.1111/j.14388677.2009.00248.x 
VAZ, F.; SANTOS-FILHO, E.; SILVA, S.; ARAÚJO, S.; STAMFORD-ARNAUD, T.; BANDEIRA, A.; BRASILEIRO-VIDAL, A. C.; STAMFORD, N. P.; MOUCO, M. A. C.; GOUVEIA, E. Biodegradation of paclobutrazol - a plant growth regulator used in irrigated mango orchard soil. In: CHAMY, R.; ROSENKRANZ, F. (eds.). Biodegradation and Bioremediation of Polluted Systems-New Advances and Technologies. London: IntechOpen, 2015. p. 85-107.

ZANDONADI, D. B.; SANTOS, M. P.; DOBBSS, L. B.; OLIVARES, F. L.; CANELLAS, L. P.; BINZEL, M. L.; OKOROKOVA-FAÇANHA, A. L.; FAÇANHA, A. R. Nitric oxide mediates humic acids-induced root development and plasma membrane $\mathrm{H}^{+}$-ATPase activation. Planta, v. 231, n. 5, p. 1025-1036, 2010. https://doi.org/10.1007/s00425-010$1106-0$ 